\title{
A PRELIMINARY STUDY OF INDONESIAN COAL BASINS FOR UNDERGROUND COAL GASIFICATION DEVELOPMENT
}

\author{
STUDI PENDAHULUAN CEKUNGAN BATUBARA INDONESIA \\ UNTUK PENGEMBANGAN GASIFIKASI \\ BATUBARA BAWAH PERMUKAAN
}

\author{
ASEP B. PURNAMA and MIFTAHUL HUDA \\ R\&D Centre for Mineral and Coal Technology \\ Jendral Sudirman Street No. 623 Bandung 40211, West Java, Indonesia \\ Telp : (022-6030483), Fax : 022-6003373 \\ e-mail : bahtiar.purnama1976@gmail.com
}

\begin{abstract}
The energy needs in Indonesia are continuing to increase, however, the production of oil and gas declines. This problem can be minimized by developing alternative energy such as underground coal gasification (UCG) by utilizing deep seated coal at 200 to $1.000 \mathrm{~m}$ below surface. The objective of this study is to evaluate coal characteristic in the basins for UCG purpose depends on several coal properties such as its rank (below bituminous), thickness $(5 \mathrm{~m})$, depth (up to $200 \mathrm{~m}$ ), and ash content plus total moisture (below $60 \%$ ). Based on coal analysis of 11 coal basins from previous exploration drilling, there were several coal layers in four selected basins to be applied for the UCG project, namely 7 coal layers in South Sumatra Basin, 7 coal layers in Barito Basin, 2 coal layers in Asam-asam Basin and 5 coal layers in Kutai Basin. Based on the SNI No. 5015-2011, the coal resources was calculated and converted into a gas by a simulation procedure. Total UCG coal in South Sumatera Basin is 801 million tons, meanwhile, the Barito Basin has 436 million tons, Asam-asam 136 million tons, and Kutai 289.7 million tons. The total hypothetical syngas is 8.38 TSCF. The UCG facilities in South Sumatra Basin should be designed to produce the syngas as the natural gas within this area is in deficit condition and the basic cost for electricity supply belongs to low situation, however, the UCG plants in Kalimantan should produce electricity as its cost ratio of electricity is high and this area retains surplus natural gas supply.
\end{abstract}

Keywords: coal, basins, underground coal gasification, electricity, synthetic gas

\begin{abstract}
ABSTRAK
Kebutuhan energi di Indonesia terus meningkat namun produksi sumber energi seperti minyak dan gas bumi semakin menurun. Masalah tersebut dapat diminimalkan melalui pengembangan energi alternatif seperti gasifikasi batubara bawah permukaan (UCG), dengan memanfaatkan batubara yang berada jauh di bawah permukaan tanah, pada kedalaman 200 sampai $1.000 \mathrm{~m}$. Tujuan penelitian ini adalah untuk mengevaluasi karakteristik batubara di cekungan batubara Indonesia yang sesuai untuk pengembangan UCG berdasarkan beberapa parameter batubara seperti tingkat kematangan di bawah bituminus, ketebalan lapisan $>5 \mathrm{~m}$, kedalaman lapisan $>200 \mathrm{~m}$, dan jumlah kandungan abu dan air total $<60 \%$. Berdasarkan data pemboran eksplorasi terdahulu, terdapat beberapa lapisan batubara di 4 cekungan yang sesuai untuk pengembangan UCG, yaitu 7 lapisan batubara di Cekungan Sumatera Selatan, 7 lapisan batubara di Cekungan Barito, 2 lapisan batubara di Cekungan Asam-asam, dan 5 lapisan batubara di Cekungan Kutai. Perhitungan sumberdaya batubara berdasarkan ketentuan SNI No. 5015-2011, kemudian disimulasikan menjadi gas. Dari hasil perhitungan Cekungan Sumatera Selatan mempunyai total sumberdaya batubara 801 juta ton, Cekungan Barito mempunyai total sumberdaya batubara 436 juta ton; Cekungan Asam-Asam 136 juta ton; Cekungan batubara Kutai 289,7 juta ton. Dari simulasi konversi perhitungan sumberdaya batubara menjadi sumberdaya hipotetik gas UCG didapatkan total sumberdaya hipotetik gas sebesar 8.38 TSCF. Fasilitas UCG di cekungan Sumatra Selatan sebaiknya didesain untuk memproduksi gas alam sintetis karena neraca gas alam di wilayah ini mengalami defisit dan biaya pokok
\end{abstract}


penyediaan listrik (BPP) di wilayah ini tergolong rendah. Sebaliknya fasilitas UCG di Kalimantan sebaiknya untuk menghasilkan listrik karena BPP listrik tergolong tinggi sedangkan pasokan gas alam di wilayah ini masih surplus.

Kata kunci: cekungan, batubara, gasifikasi batubara bawah permukaan, kelistrikan, gas alam sintetis

\section{INTRODUCTION}

Energy consumption in Indonesia continually increases due to the positive economic and population growth. Under business as usual (BAU) scenario, the total final energy demand will increase from 238.8 MTOE (Million Ton Oil Equivalent) in 2025 to 682,3 MTOE in 2050 (Dewan Energi Nasional, 2017). Based on the National Energy Policy, the National Energy Policy, the enormous Indonesia energy demand in the future will be managed through energy resource conservation and energy use diversification. The policy shall be performed at least through substituting fuel oil with gas, utilizing electric power for the propulsion motor vehicles; increasing utilization of low-rank coal for mine mouths steam power plant gasified coal and liquefied coal; and increasing utilization of the medium and high-rank coals for domestic power plant.

One of the methods to perform energy conservation is optimizing the use of deepseated coal through the implementation of coal bed methane (CBM) or underground coal gasification (UCG) technology. CBM technology extracts the methane gas that is trapped in the coal seams by constructing the wells into the coal seam as well as pumping out the water from the wells. The purpose is to decrease the water pressure in the coal seams. Methane adsorbed into a solid coal matrix (coal macerals) will be released if the coal seam is depressurized. The decrease in pressure allows the methane to desorb from the coal and flow as a gas through the well to the surface. The methane is then compressed and piped to the market.

Both the government and private sectors have been engaged in CBM development in Indonesia. Between 2008 and 2015, a total of 54 CBM working areas, mainly around Sumatra and Kalimantan were granted to by Government of Indonesia (GOI) to the private companies. In addition, Geological Agency actively assists the private company to conduct CBM explorations. From the year
2006 to 2016 fourteen (14) research sites have been explored and about 99,901.94 BCFCBM resources have been found (Pusat Sumberdaya Mineral Batubara dan Panas Bumi, 2016).

Underground coal gasification (UCG) involves injecting the steam and air or oxygen $\left(\mathrm{O}_{2}\right)$ into a coal seam from a surface well. The injected gases react with the coal to form a combustible gas which is brought to the surface in production well. Figure 1 illustrates the UCG process. In addition to gas that is produced by gasification reaction, the UCG also extract methane gas trapped in the coal seam, therefore it produces combustible gas with a much larger volume than CBM.

The predominant gas products are methane, hydrogen, carbon monoxide and carbon dioxide. The gas output may be combusted for electricity production. Alternatively, the syngas (hydrogen and carbon monoxide) can be used as a chemical feedstock for the production of synthetic natural gas, fuels (e.g. diesel), fertilizer, explosives, and other products.

UCG for electricity has been studied by several researchers (Nakaten et al., 2014; Nakaten, Islam and Kempka, 2014; BurchartKorol et al., 2016; Maev, Blinderman and Gruber, 2018). The magnitude of UCG product cost depends on several variables including coal seam depth, seam thickness, seam thickness to cavity width ratio, coal CV, $\mathrm{CO}_{2}$ emission charges, average drilling costs, oxidizer production costs, synthesis gas processing costs, and nominal interest rate. If pure oxygen is used for gasification, $20.5 \%$ of $\mathrm{CO}_{2}$ is processed by CCS (Carbon capture and storage) and the remaining $79.5 \% \mathrm{CO}_{2}$ emission is charged at $25 € /$ ton, the cost of UCG for electricity is $71.67 € / M W h$ (centUSD 8.2/kWh) (Nakaten et al., 2014). Among the electricity cost components, the cost for oxygen contributes the highest (Nakaten, Islam and Kempka, 2014). The cost of electricity above is lower than that of electricity in the east and north Kalimantan. It is about USD 11 cents /kWh. 


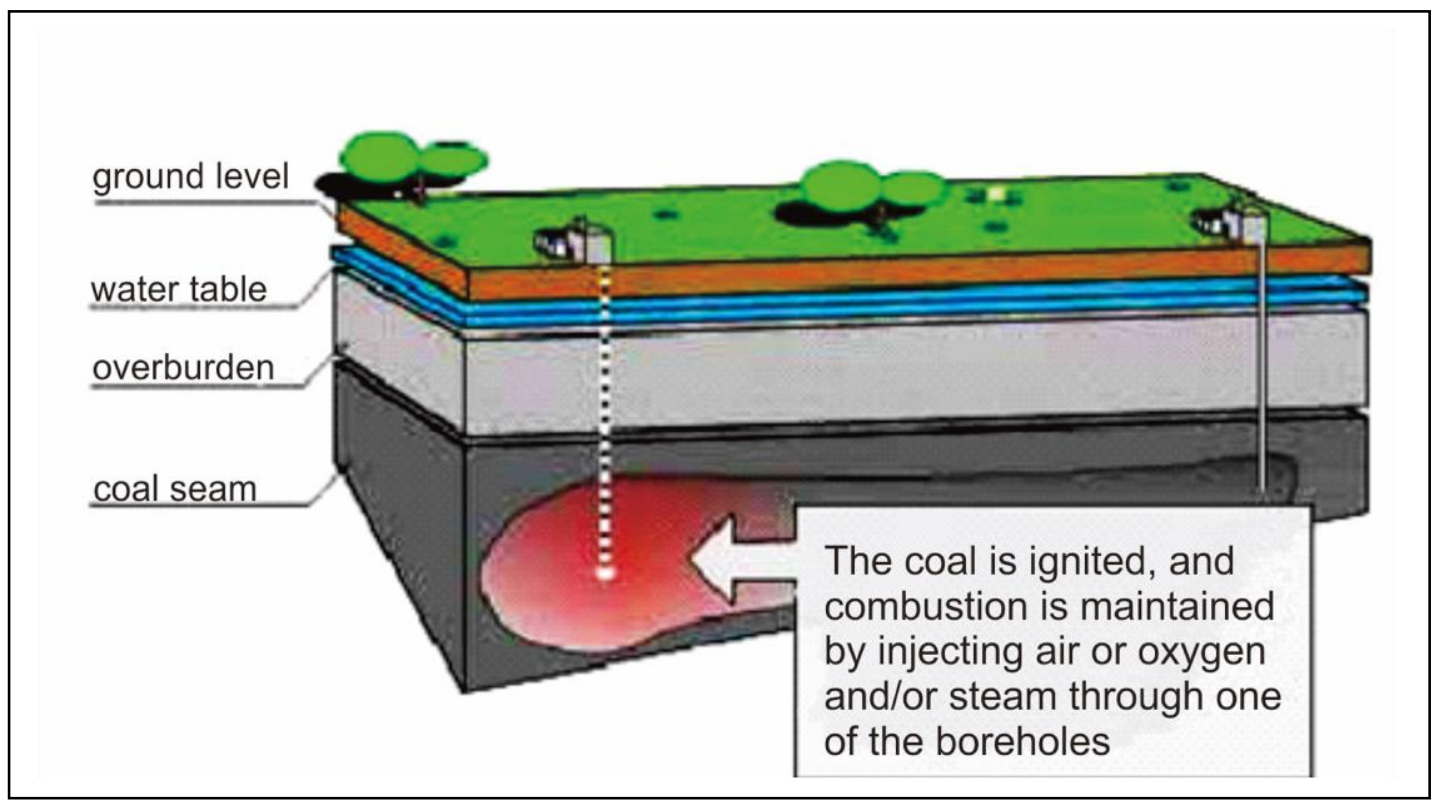

Figure1. Underground Coal Gasification process (Hattingh, 2008)

Kreynin (2012) studied the use of UCG syngas for synthesizing 220 thousand tons liquid hydrocarbons, 100 million $\mathrm{m}^{3}$ gaseous (methane butane) and $800 \mathrm{MW}$ power, and found the payback period of investments of such an object is about 5 years. According to the carbon energy, the cost to produce pipeline quality natural gas from Carbon Energy's UCG Syngas was estimated to be in the range of $\$ 3.50 / \mathrm{GJ}$ to $\$ 4.50 / \mathrm{GJ}$ (excluding carbon tax and other taxes). It is believed that producing electricity and synthetic fuel from the UCG syngas is economically viable.

Based on a technical and economical point of view, there are some conditions to be met in order to utilize coal deposit for UCG. The conditions include coal characteristics (thickness, rank, ash and moisture contents, depths, and availability of fracture/cleat in coal), geological structure and overburden properties (Santoso, 2015). The coal rank for UCG development should be bituminous coal or lower rank (Oliver and Dana, 1991; Khadse et al., 2007; Friedmann, Upadhye and Kong, 2009; Kreynin, 2012; Bhutto, Bazmi and Zahedi, 2013; Imran et al., 2014). It needs to study coal characteristics as well as its depth, thickness, quality, structure condition and overburden (Santoso, 2015). The geological structure around the UCG should be qualified as simple and the immediate layer between the overburden and under burden rock should be impermeable (Santoso, 2015). Since there are some conditions to be met, not all Indonesian coal deposit can be extracted using the UCG method.

Detail studies including site characterization, products option, market, infrastructure, etc., should be conducted in order to select a suitable site for UCG. In this study coal resources from the limited drill hole, data will be calculated and the alternative use of UCG gas will be elaborated. The objective of this study is to find the most suitable options for UCG gas utilization in several coal deposit.

\section{METHODOLOGY}

The steps of this study include coal drilling data collection, coal resources, and UCG product gas calculation and elaboration of UCG gas utilization for electricity and for substitute natural gas. Oil drilling data listed in the report of Advanced Resources International, Inc., (ARI) 2003, were used to obtain coal seam depth data. Coal resource was calculated using SNI 5015-2011 (Badan Standardisasi Nasional, 2011), about the guidance of coal resources and reserves report. The coal resources data then were converted into synthetic natural gas by assuming gasification and syngas conversion 
efficiency $50 \%$ and coal resource use efficiency $60 \%$ using the following formula.

$$
\mathrm{GR}=\frac{3.97 \times \mathrm{T} \times \text { RUef } \times \text { Gef } \times \text { Chv }}{\text { NGhv } \times 10^{12}}
$$

$$
\begin{array}{ll}
\mathrm{GR} & =\text { UCG gas resources (TCF) } \\
\mathrm{T} & =\text { Coal Tonnage (Ton) }
\end{array}
$$

RUef = Resource utilization efficiency $60 \%$

Gef = Gasification and syngas conversion efficiency $50 \%$

Chv = Coal heating value, 6000,000 $\mathrm{kcal} / \mathrm{ton}$.

$1 \mathrm{kcal}=3.97 \mathrm{BTU}$

$1 \mathrm{TCF}=1012 \mathrm{CF}$

NGhv = Natural gas heating value, 1000 BTU/CF

The supply-demand of electricity data in this paper was derived from RUPTL 2018-2027. RUPTL document contained PLN business plan based on detailed calculations of electricity demand and the subsequent transmission and distribution requirements in Indonesia. PLN is Indonesia state-owned company for electricity business.

\section{GEOLOGICAL CONDITIONS}

The territory of Indonesia is based on its geological condition flanked by two large crusts of the earth's crust namely the Indian-
Australian Plate and the Pacific Plate. The existence and activity of these plates caused the emergence of a volcanic arc, plate subduction zones, and sedimentation basins (Darman and Sidi, 2000). The sedimentation basin can produce the potential of petroleum, natural gas, and coal, depending on the composition of sediment-forming material and its sedimentary environment (Hall, 2009).

Based on the concept of the tectonic plate, Indonesia coal sedimentary basin has tertiary age and located in the western part of Indonesia and well known as the back arc basin, fore arc basin, and intramountain. Each of these basins has different characteristics of coal deposits. Generally, the tertiary coal basins in Indonesia are classified into a type of shelf-basin, except Kutai and Tarakan Basins in East Kalimantan that are classified as continental margins.

All of Indonesia's coal deposits were formed in the Tertiary era. However, it can be distinguished the Paleogene coal (coal deposits formed in intercellular basins, among others are found in Ombilin, Bayah, southeastern Kalimantan and South Sulawesi) and the Neogen coal (the coal formed in the foreland basin, which is found in Tanjung Enim, and delta deposits which are found in almost all coal deposits in East Kalimantan) as shown in Figure 2.

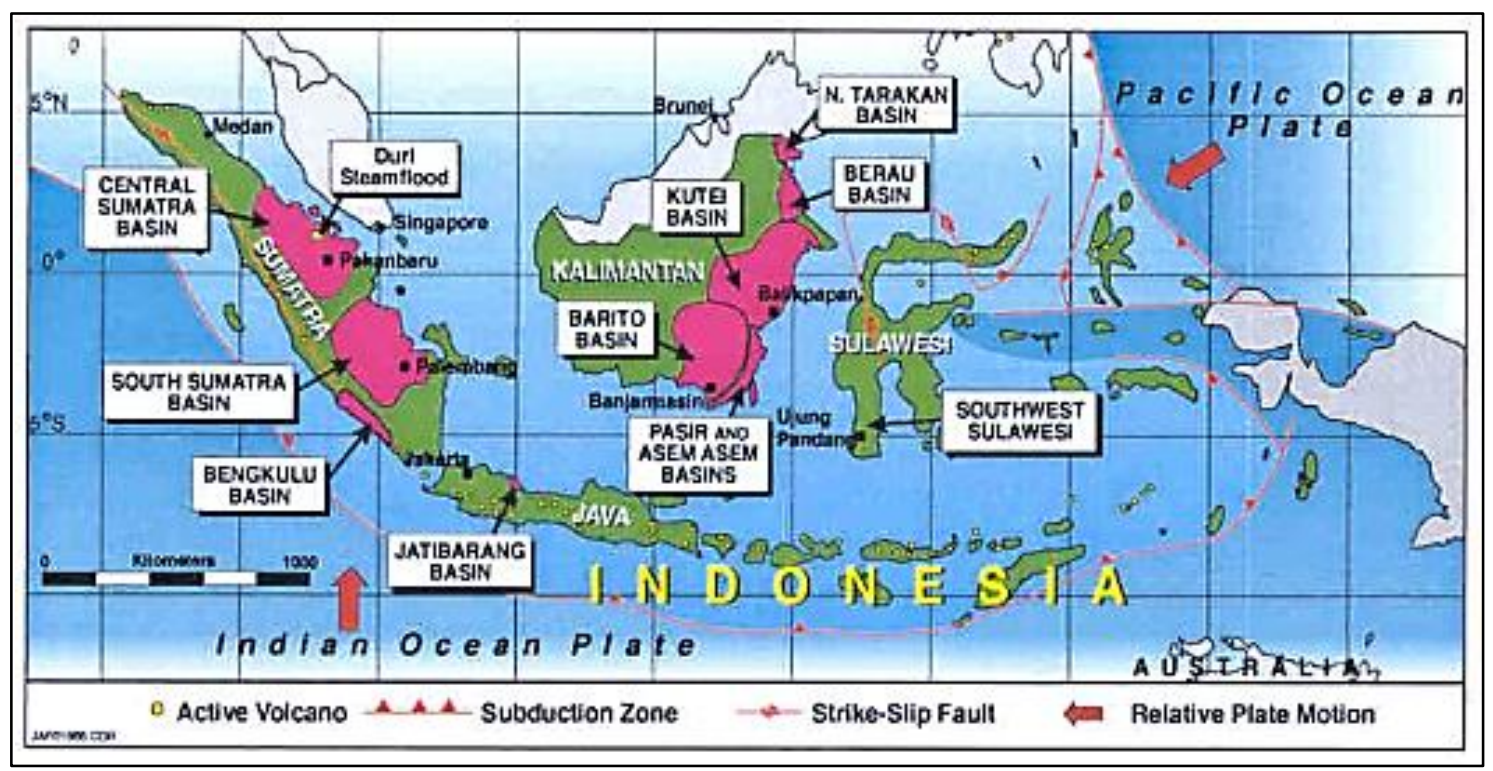

Figure 2. Coal potential basins (Advanced Resources International, 2003) 
The coal-bearing formation innumerous basins in Indonesia is considered to be the most potential basin to develop for UCG. There are 11 basins to be the candidates, most of them are generally concentrated in the western part of Sumatra and Kalimantan. However, there are two basins located outside those two islands, such as Sulawesi Basin in Sulawesi and Jatibarang Basin, Java. Advanced Resources International (2003) also determined those basins for CBM development among many basins in Indonesia.

\section{Basins in Sumatra Island}

Sumatra is a part of the Sunda continental platform. The oceanic crust underlies the Indian Ocean is included in the Indo-Pacific plate, subducting along the Sunda trench outside the west coast of Sumatra. The subduction resulted in a magmatic arc forming of the Bukit Barisan Mountains. In connection with this magmatic arc, it is formed in several zones such as accretion, fore arc, and back arc. The main fault parallel to the island also occurs.

Base on its tectonic setting, the coal basins in western Indonesia can be divided into forearc, Paleogene intercontinental mountain, and neogen-back arc basins. The crosssection that intersects Central Sumatra in the southwest-northeast direction can be seen in Figure 3. Until now, it has been recognized 2 (two) main basins which are deposited in the back arc and become the target of coal exploration and production in Sumatera, namely South Sumatera and Central Sumatera basins. The two basins are separated by Tigapuluh high, located between Riau and Jambi Provinces.

Meanwhile, the coal basin located near the magmatic arc of Sumatra Island will be an intra-mountain basin as seen in Ombilin and KiliranJao areas. Coal deposits in the Bengkulu basin are located between the magmatic and the fore arc basins which formed Bengkulu Basin.

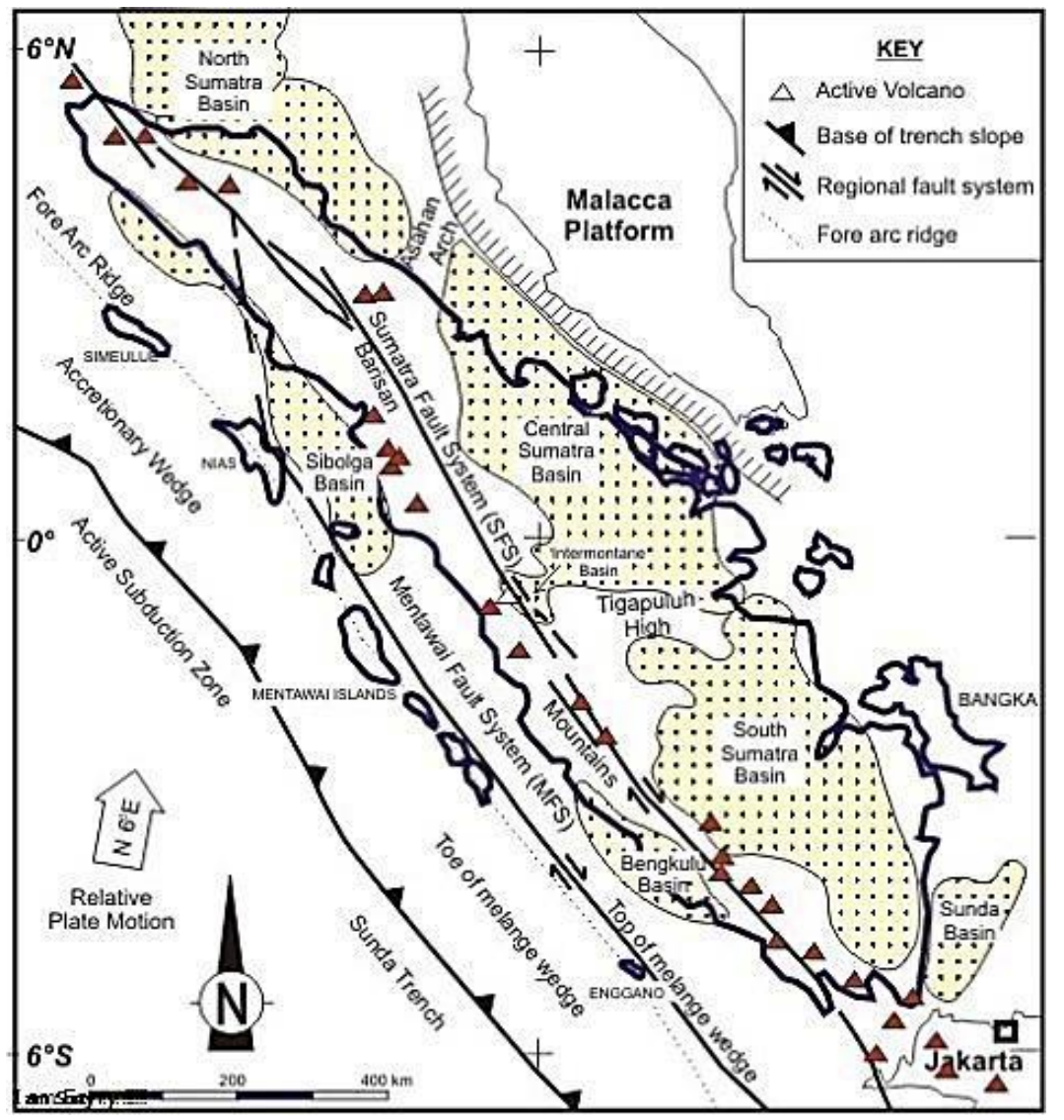

Figure 3. Coal basin in Sumatera Island (Darman and Sidi, 2000) 


\section{Borneo Basins}

Physiographically, Borneo consists of several zones, from south to north (van Bemmelen, 1949). Those are (Figure 4):

- Sebuku Island, Makassar Strait Zone, Kutai and Mahakam.

- Mangkalihat Zone

- Karimata Zone, Sampit, Pangkalanbun and Palangkaraya.

- Pontianak and Sambas Zones.

- Kuching Zone, Ketungau and TanjungSelor.

- Sarawak and Tarakan Zones.

- Sibu Zone, Brunei and "Sulu Trough".

The former researchers divided the Borneo island into several zones based on several characteristics, from the different lithostratigraphy, chronostratigraphy, biostratigraphy, geological and developed tectonic structures, as well as physiographic differences, geomorphological characteristics, mineral resource potentials and its hydrocarbon potential.

One of the prospect areas for hydrocarbons lies within the Mahakam and Kutai Basin Zones now it is near the Mahakam River. In the middle of the Tertiary Period, many sedimentary rocks occurred in the Mahakam and Kutai Basins, whether they are formed in deep-sea environments, shallow seas, lagoons, Delta or transitional and exposure environments.

In certain deposition environments either transitions or deltas, there are many coal seams in various thicknesses, characteristics, qualities, and structural patterns. Those affect seams with the coal-bearing formation. In this area, the coal-bearing rocks belong to carbonaceous claystone and siltstone. Based on its physiography development, the pattern of coal distribution influenced strongly by the regional geological structure and the tectonics.

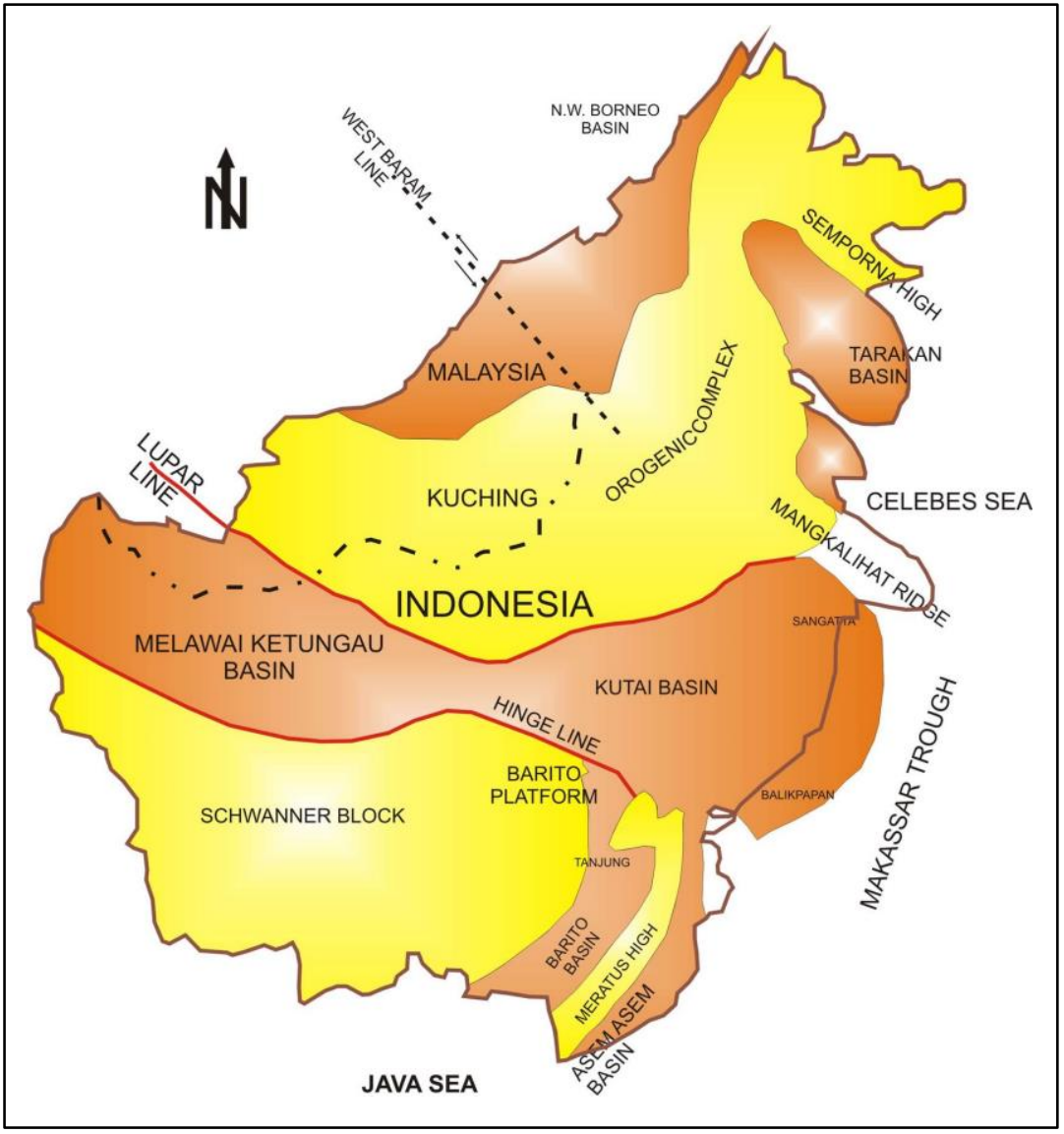

Figure 4. Borneo coal basins (van Bemmelen, 1949) 
Borneo Island has five main basins containing a large amount of potential coal. The five potential basins are found in East, South and Central Kalimantan.

\section{South Sulawesi Basins}

Based on the Regional Geology of Sulawesi (Sukamto, 1982), coal in South Sulawesi can be found in several formations, including the Mallawa, Walanae, Camba, and Toraja Formations with different characteristics in each Formation. In general, coal in South Sulawesi includes lignite as it formed in the Tertiary era, Eocene and Neogene aged. Coal in Toraja Formation has a variable thickness, some of them have a thickness of more than $4 \mathrm{~m}$ and a dip of less than $30^{\circ}$. The coal in Walanae Formation has a thickness of $0.5 \mathrm{~m}$ (Advanced Resources International, 2003).

\section{Jatibarang Basins}

Jatibarang Basin is an oil and gas production area in the north-west of Java Island, it is located between the cities of Jakarta and Cirebon. This basin is also estimated to have prospective CBM even in small quantities. In the Southwest of West Java, deposited 14 layers of Eocene Cimandiri and Bayah Coal Formation which laterally spotted. In Jatibarang Basin, it was found Oligocene coal which can be compared to the coal from Talang Akar Formation which is Miocene age.

\section{RESULTS AND DISCUSSION}

The segmentation of coal resource allocation for UCG is almost the same as coal for CBM that is at a depth between 200 and $1,000 \mathrm{~m}$.

In this preliminary research coal for UCG, the coal parameter should be specified as follows: the coal rank below bituminous, coal layer thickness more than $5 \mathrm{~m}$, coal layer depth more than $200 \mathrm{~m}$ and sum of ash plus moisture content must be below $60 \%$, so from numbers of coal layers in 11 basins, there are only several layers fulfill the specification in four basins, 7 coal layers in South Sumatera basin, $7 \mathrm{coal}$ layers in
Barito basin, 2 coal layers in Asam-asam basin and 5 coal layers in Kutai Basin.

The coal layers resources and reserves, and hypothetic gas for UCG study in 4 potential basins can be seen as follows:

1. South Sumatera basin (7 coal layers) with a thickness variation of 5 to $22 \mathrm{~m}$ at a depth of 200 to $600 \mathrm{~m}$ with average vitrinite reflectance of $0.47 \%$ and is included into the sub-bituminous rank, having ash value $10 \%$, moisture value $7.5 \%$, it has the measured resources 89 million tons, indicated resources 267 million tons, and inferred resources 445 million tons, the hypothetical gas resources of 4.77 TCF (see Figure 5, Table 1);

2. Barito basin (7 layers of coal) with a thickness variation of 5 to $8.5 \mathrm{~m}$ at a depth of 500 to $1,000 \mathrm{~m}$, an average value of $0.45 \%$ vitrinite reflectance and is included into the sub-bituminous rank, having ash value of $10 \%$, moisture value $10 \%$, it has the measured resources of 48.5 million tons, indicated resources of 145.5 million tons and inferred resources of 242.5 million tons, the hypothetical gas resources of 1.828 TCF (Figure 6, Table 2);

3. Pasir/Asem-asem basin (2 layers of coal), with a thickness variation of 7 to 8 $\mathrm{m}$ at a depth of 300 to $750 \mathrm{~m}$ with average vitrinite reflectance of $0.45 \%$ and is included into sub-bituminous rank, the ash value and the moisture content is $7.5 \%$, measured resources is 15.2 million tons, while the indicated resources are 45.5 million tons, and inferred resources are 78.9 million tons, respectively its gas hypothetical resource is $0.574 \mathrm{TCF}$ (Figure 7, Table 3);

4. Kutai basin (5 seams of coal), retains thickness of 7 to $8 \mathrm{~m}$, depth of 200 to 800 $\mathrm{m}$, with average vitrinite reflectance of $0.5 \%$ vitrinite, and is included into the sub-bituminous rank, performing the ash value and moisture content of $7.5 \%$. Its measured resources are 32.2 million tons, The indicated resources are 96.5 million tons, and the inferred resources is 160.9 million tons, it has hypothetical gas resources 1.205 TCF (Figure 8, Table 4). 
INDONESIAN MINING JOURNAL Vol. 22, No. 1, April $2019: 61$ - 76

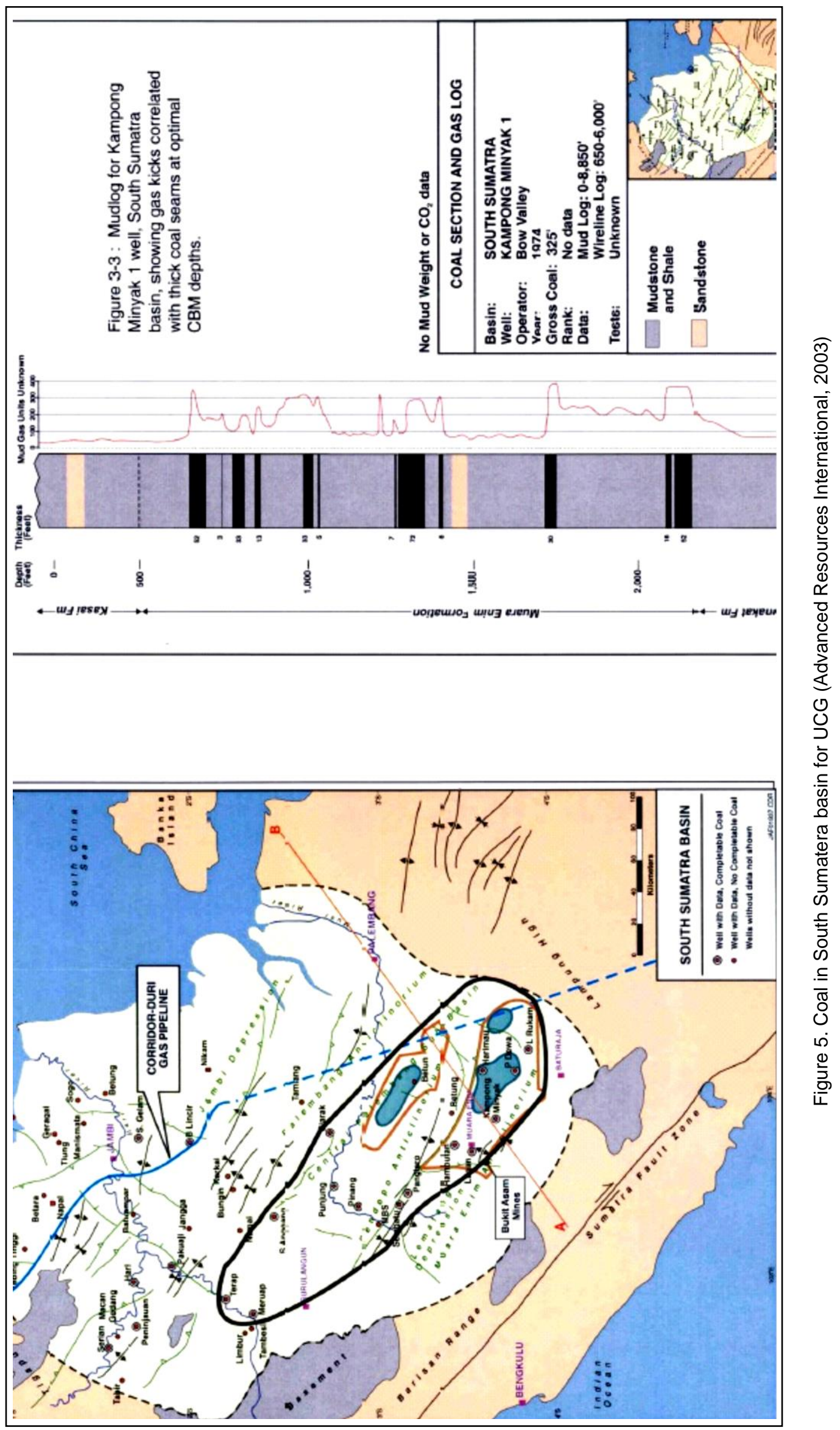


A Preliminary Study of Indonesian Coal Basins for ... Asep B. Purnama and Miftahul Huda

Table 1. South Sumatera basin resources (coal and gas)

\begin{tabular}{cccccc}
\hline \multicolumn{5}{c}{ South Sumatera Basin } \\
\hline \multirow{2}{*}{ No } & \multirow{2}{*}{ Seam } & Seam & \multicolumn{3}{c}{ Coal Resources } \\
\cline { 3 - 6 } & & Thickness & Measured & Indicated & Inferred \\
\hline 1 & Coal 1 & 15.76 & $16,083,080$ & $48,249,240$ & $80,415,400$ \\
2 & Coal 2 & 10 & $10,205,000$ & $30,615,000$ & $51,025,000$ \\
3 & Coal 3 & 10 & $10,205,000$ & $30,615,000$ & $51,025,000$ \\
4 & Coal 4 & 22 & $22,267,310$ & $66,801,930$ & $111,336,550$ \\
5 & Coal 5 & 9 & $9,286,550$ & $27,859,650$ & $46,432,750$ \\
6 & Coal 6 & 5 & $4,898,400$ & $14,695,200$ & $24,492,000$ \\
7 & Coal 7 & 15.75 & $16,072,875$ & $48,218,625$ & $80,364,375$ \\
\hline \multicolumn{7}{c}{$89,018,215$} & $267,054,645$ \\
\hline
\end{tabular}

Table 2. Barito basin resources (coal and gas)

\begin{tabular}{|c|c|c|c|c|c|}
\hline \multicolumn{6}{|c|}{ Barito Basin } \\
\hline \multirow{2}{*}{ No } & \multirow{2}{*}{ Seam } & Seam & \multicolumn{3}{|c|}{ Coal Resources } \\
\hline & & Thickness & Measured & Indicated & Inferred \\
\hline 1 & Coal 1 & 7.5 & $7,653,750$ & $22,961,250$ & $38,268,750$ \\
\hline 2 & Coal 2 & 7.5 & $7,653,750$ & $22,961,250$ & $38,268,750$ \\
\hline 3 & Coal 3 & 5 & $4,980,040$ & $14,940,120$ & $24,900,200$ \\
\hline 4 & Coal 4 & 8.54 & $8,715,070$ & $26,145,210$ & $43,575,350$ \\
\hline 5 & Coal 5 & 8.54 & $8,715,070$ & $26,145,210$ & $43,575,350$ \\
\hline 6 & Coal 6 & 5.76 & $5,878,080$ & $17,634,240$ & $29,390,400$ \\
\hline \multirow[t]{4}{*}{7} & Coal 7 & 4.8 & $4,898,400$ & $14,695,200$ & $24,492,000$ \\
\hline & & & $48,494,160$ & $145,482,480$ & $242,470,800$ \\
\hline & & & \multicolumn{3}{|c|}{ Gas Resources Hypothetic (TSCF) } \\
\hline & & & 0.203 & 0.61 & 1.015 \\
\hline
\end{tabular}

Table 3. Asem-asem basin resources (coal and gas)

\begin{tabular}{|c|c|c|c|c|c|}
\hline \multicolumn{6}{|c|}{ Asem-asem Basin } \\
\hline \multirow{2}{*}{ No } & \multirow{2}{*}{ Seam } & Seam & \multicolumn{3}{|c|}{ Coal Resources } \\
\hline & & Thickness & Measured & Indicated & Inferred \\
\hline 1 & Coal 1 & 7 & $7,143,500$ & $21,430,500$ & $35,717,500$ \\
\hline \multirow[t]{4}{*}{2} & Coal 2 & 8 & $8,031,335$ & $24,094,005$ & $40,156,675$ \\
\hline & & & $15,174,835$ & $45,524,505$ & $242,470,800$ \\
\hline & & & \multicolumn{3}{|c|}{ Gas Resources Hypothetic (TSCF) } \\
\hline & & & 0.064 & 0.19 & 0.32 \\
\hline
\end{tabular}

Table 4. Kutai basin resources (coal and gas)

\begin{tabular}{cccccc}
\hline \multicolumn{5}{c}{ No } & \multirow{5}{*}{ Kutai Basin } \\
\cline { 3 - 5 } & Seam & Seam & Coal Resources \\
\cline { 3 - 5 } & Thickness & Measured & Indicated & Inferred \\
\hline 1 & Coal 1 & 5 & $4,898,400$ & $14,695,200$ & $24,492,000$ \\
2 & Coal 2 & 7 & $6,806,735$ & $20,420,205$ & $34,033,675$ \\
3 & Coal 3 & 8 & $8,041,540$ & $24,124,620$ & $40,207,700$ \\
4 & Coal 4 & 6.1 & $6,225,050$ & $18,675,150$ & $31,125,250$ \\
5 & Coal 5 & 6.1 & $6,225,050$ & $18,675,150$ & $31,125,250$ \\
\hline & & & $32,196,775$ & $96,590,325$ & $160,983,875$ \\
\hline
\end{tabular}

Gas Resources Hypothetic (TSCF)

$\begin{array}{lll}0.135 & 0.4 & 0.67\end{array}$




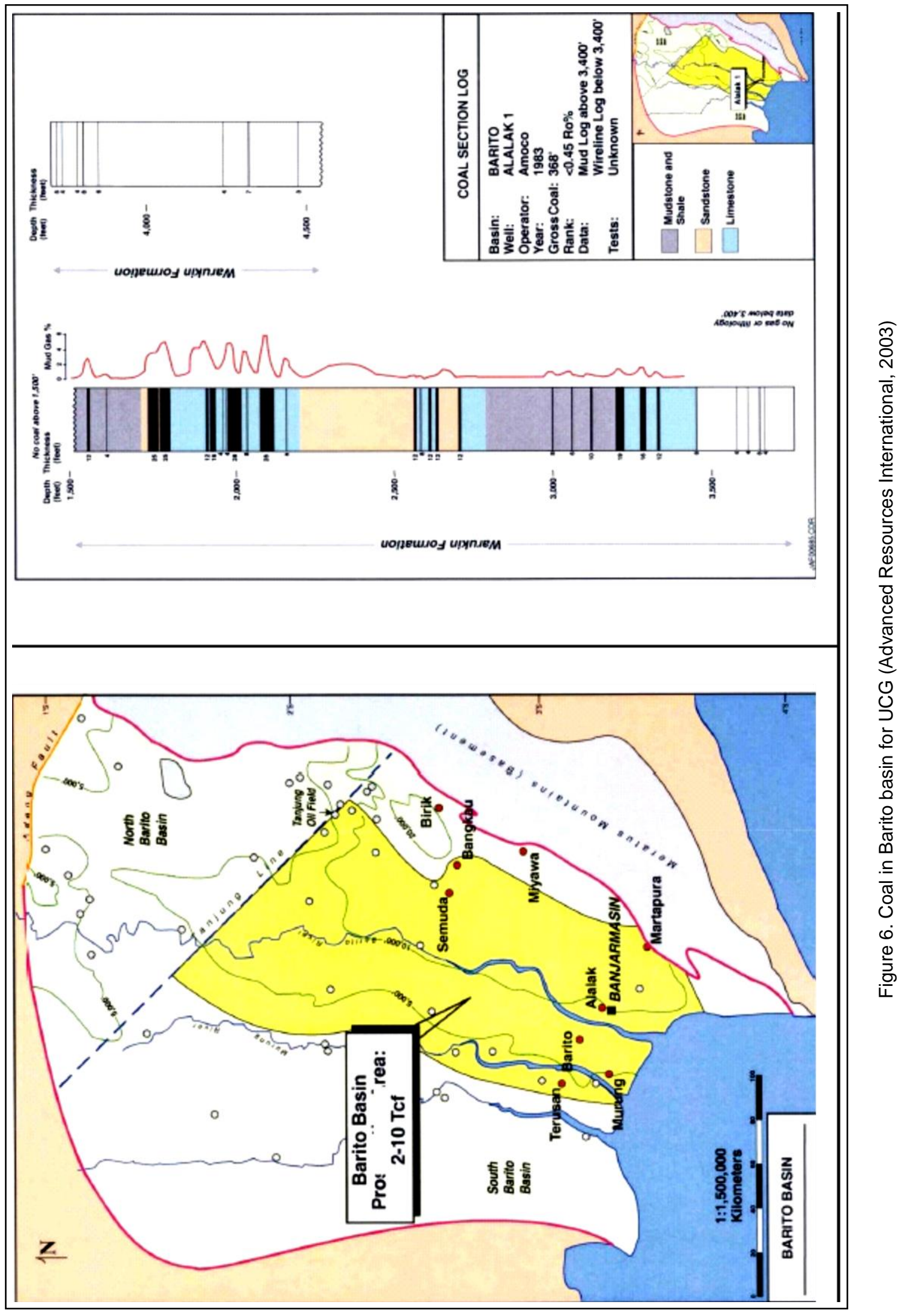




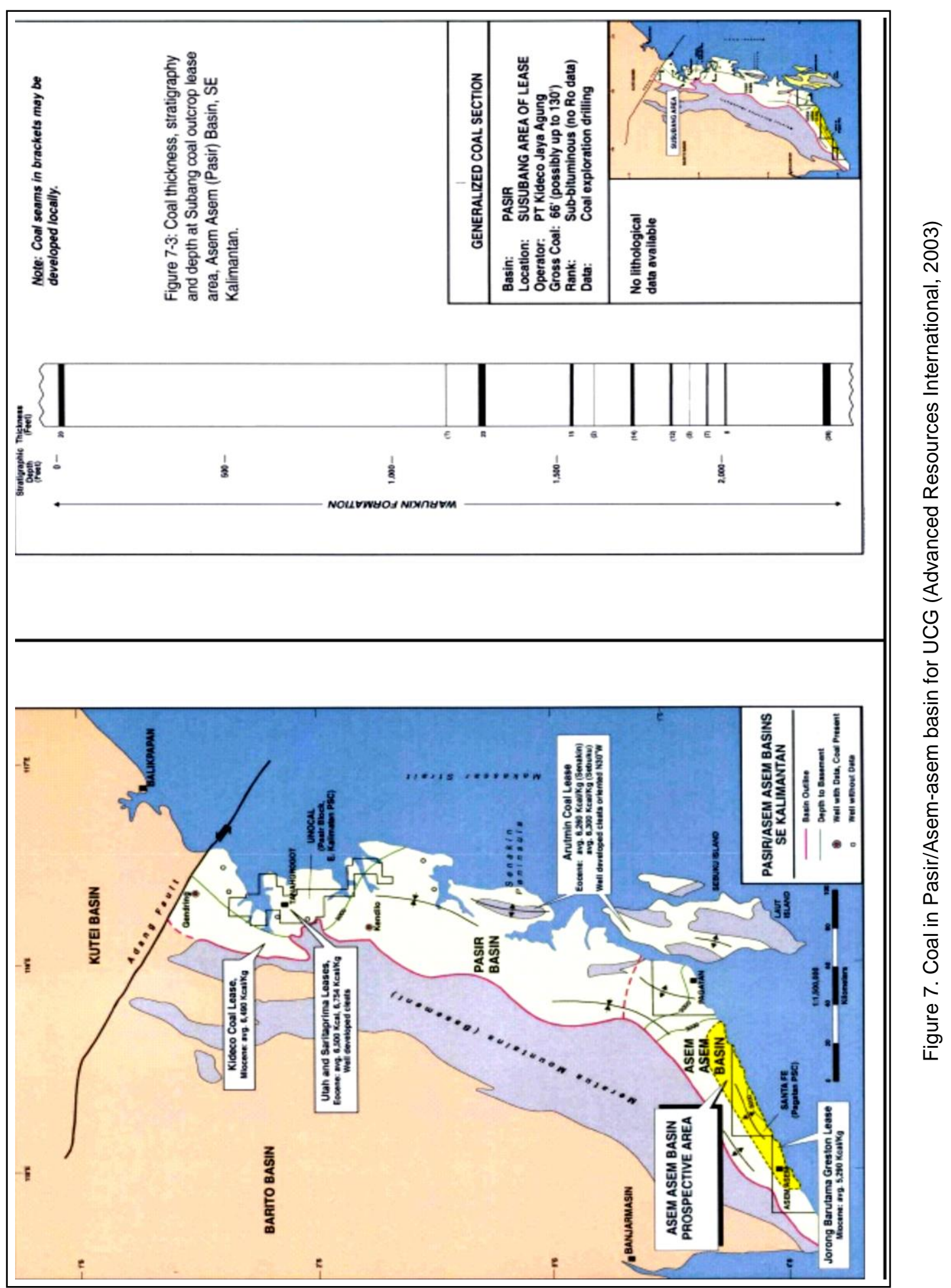


INDONESIAN MINING JOURNAL Vol. 22, No. 1, April $2019: 61$ - 76

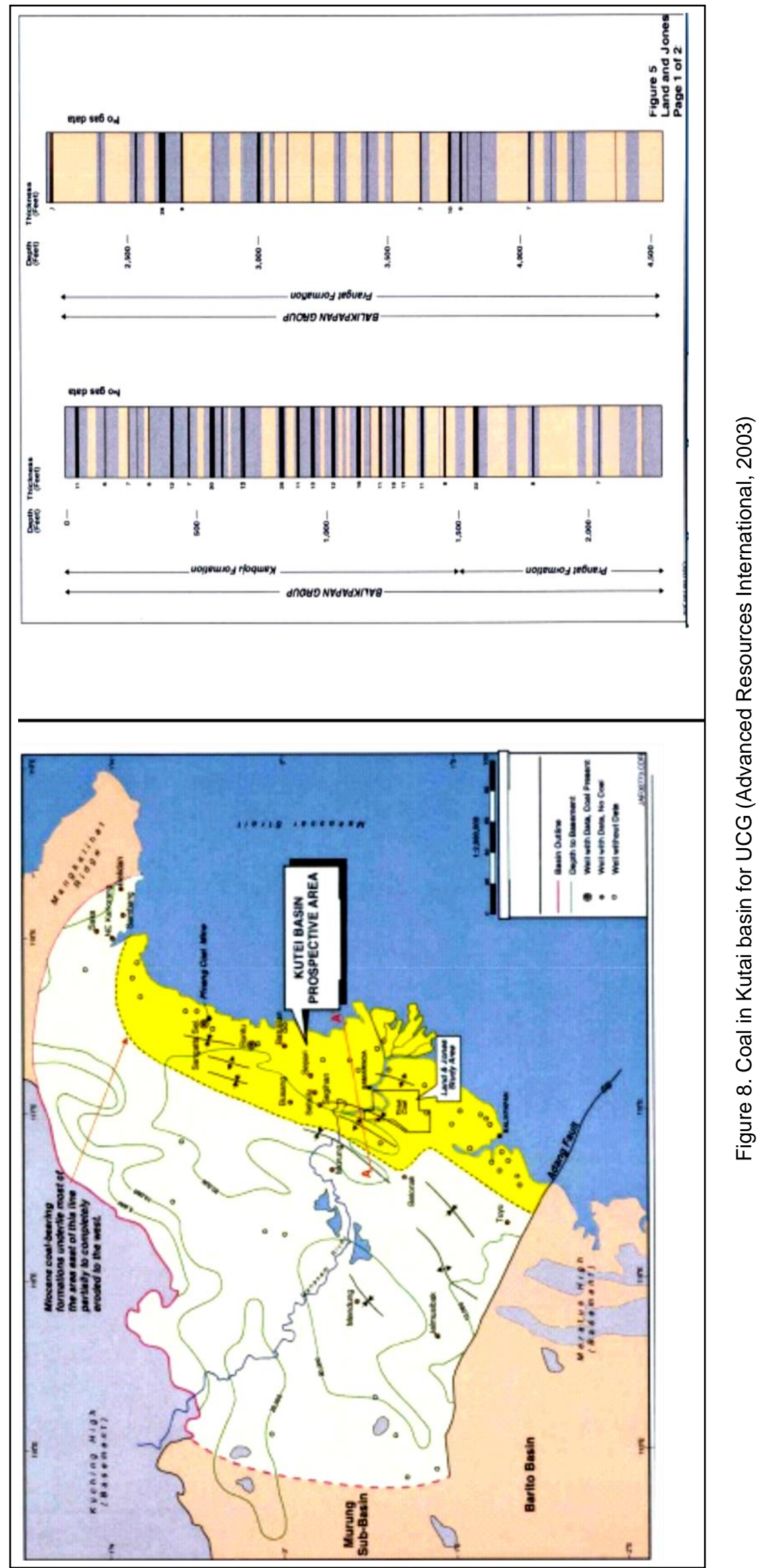




\section{UCG GAS UTILIZATION}

A product of underground coal gasification is combustible gas which can be used in the energy and chemical industry. In this paper, the potential use of UCG gas for electricity and natural gas substitution in the four coal basins were investigated. The synthetic natural gas may be transmitted using existing natural gas pipeline for further processing into chemical or fuels (Figure 9).

\section{South Sumatera Basin}

The South Sumatra Province has various energy resources such as petroleum, natural gas, coal and geothermal. The province also has a very strategic location since it is close to Java Island and is an international trade route connecting Thailand, Malaysia, Singapore, and Indonesia. Due to the above comparative advantages, the local government sets a program to exploit their energy resources for fulfilling national energy needs (2006-2025 South Sumatera master plan). The electricity surplus from this province has been supplied to other provinces.

In 2017, electricity sales in the province were 4,705 GWh while the rated capacity of the power plant and peak loads were 2,029 MW and $831 \mathrm{MW}$, respectively. This large electricity surplus(the difference between rated power and peak load) indicates that the province can supply electricity to other regions. This surplus may be maintained in the next period since in $2018-2027$ several new power plants will be built with a total capacity of $3,846 \mathrm{MW}$, most of which $(3,290$ MW) as mine mouth coal-fired power plants (MMPP). Therefore, the construction of the UCG Plant to produce electricity must compete with conventional MMPP which already has a low production cost of electricity. In addition, the main cost of electricity supply (cost ratio for electricity/CRE) in this region has already low. CRE in southern Sumatra, Jambi and Bengkulu provinces is USD 7.18 cent / kWh (Minister of Energy and Mineral Resources, 2018).

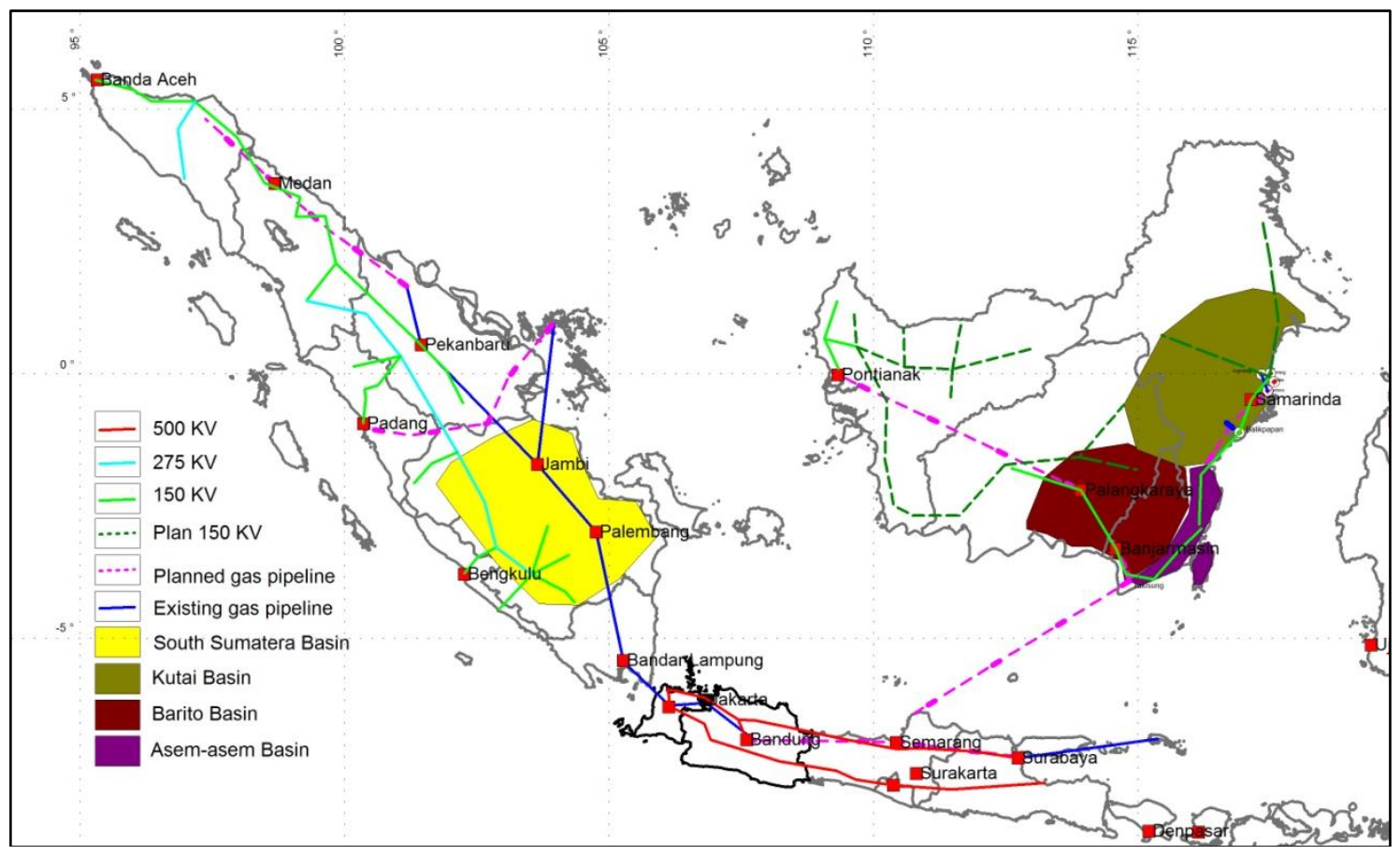

Figure 9. Coal basin, gas pipeline and electric transmission line in Sumatera and Kalimantan (modified from PT PLN, 2018 and Minister of Energy and Mineral Resources, 2012) 
There is an opportunity to produce synthetic natural gas in South Sumatera since there will be a deficit in the natural gas balance in the region. The Indonesian government has published natural gas balance (NGB) that map supply and demand in six regions across the country. Southern Sumatra Region, Central Sumatra, Riau Islands, and Western Java is in Region II. It is a region with the largest natural gas supply in Indonesia. In the year 2018, the natural gas supply in this region is estimated to reach 2,832.66 MMSCFD. According to NGB, the region will experience a deficit in natural gas supply from 2021-2027. Therefore, construction of UCG Plant in the South Sumatra basin to produce synthetic natural gas is a strategic option to improve NGB in the region.

UCG coal resources calculated from 7 (seven) coal seam is about 801 million tons. Assuming $60 \%$ of resources use efficiency and $50 \%$ of coal to synthetic natural gas efficiency, 4.8 TSCF of SNG will be obtained if the above resources are gasified and the syngas is converted to SNG. South Sumatran Basin covers a wide area, $300 \mathrm{x}$ $510 \mathrm{~km}^{2}$. Additional drilling will increase the amount of coal resources. According to the CMCGR (2016), deep-seated resources in the Sumatran region are greater than 22 billion tons, or equivalent to 131 TSCF of natural gas. In addition, in the South Sumatera basin, there is a thick coal seam (up to $22 \mathrm{~m}$ ). Huge UCG coal resources and thick coal seam allow designing high capacity of UCG to SNG facility to minimize gas deficit in region II.

\section{Barito and Pasir/Asem-asem Basin}

Based on data from BPS Statistics Indonesia, South Kalimantan province economy mainly relies on oil, gas and mining sectors although the trend of income from oil and gas is to decline continually. In order to maintain economic growth, the province should promote non oil and gas industry such as downstream industries of coal.

The selection of coal downstream products depends on the price and the competitors of the product. UCG for electricity in South Kalimantan will create greater revenue than that in South Sumatera since electricity CRE for South Kalimantan, USD 8.58 cent/ kWh is higher than for South Sumatra (Minister of Energy and Mineral Resources, 2018). The estimated peak load of the electricity system in this province in 2018 and 2027 is $480 \mathrm{MW}$ and $964 \mathrm{MW}$, respectively. Therefore, every year additional power plant with a capacity of $50 \mathrm{MW}$ is needed. The use of high efficiency such as combined cycle power plant from UCG is suggested in order to compete with the mine-mouth power plant. Combined cycle turbines fired UCG gas power plant can reach efficiency up to $45 \%$ with electricity production costs less than USD $4 \mathrm{cent} / \mathrm{kWh}$ (Maev, Blinderman and Gruber, 2018).

UCG coal resources form Barito and Asamasam basins are 573 million tons and equal to $2.4 \mathrm{TSCF}$ of natural gas.

Based on the NGB document, all provinces in Kalimantan are included in Region V. In this paper, UCG for SNG option in South Kalimantan and in East Kalimantan, therefore, will be discussed together in the same chapter.

\section{Kutai Basin}

Kutai Basin covers an area of about 43.680 $\mathrm{km}^{2}$ and mostly locates in the East Kalimantan province. UCG coal resources in this basin based on the data from the five coal seams resources in the Kutai basin are 289 million tons equal to 1.2 TSCF of natural gas. However, according to the geological agency (Pusat Sumberdaya Mineral Batubara dan Panas Bumi, 2016), deepseated resources in the Kalimantan region are greater than 20.9 Billion Tons or equivalent to 124 TSCF of natural gas

The option of UCG for electricity in East Kalimantan is economically more viable due to the existence of huge coal resources in a wide area, high electricity BPP and the existence of many isolated electricity systems in the province. CRE of electricity in East Kalimantan Province, cent-US\$ $11.07 / \mathrm{kWh}$, is higher than in South Kalimantan and South Sumatra. A number of electrical systems in several districts, West Kutai (Melak), East Kutai (Sangatta) and Mahakam Ulu (Long Bangun) in East Kalimantan, is still isolated from interconnected transmission network. The above district used diesel engine generator sets (PLTD) which experience expensive 
electricity generating cost due to the use of diesel oil. Therefore, electricity CRE in isolated electricity systems in Kalimantan is very high (cent-US\$20/kWh) (Minister of Energy and Mineral Resources, 2018).

Gas engine fueled by low heating value gas derived from coal gasification has been used in power plants (Coal Gas Power Plant/CGPP). Using a similar gas engine, small scale UCG power plant may be constructed in several districts of East Kalimantan to replace the Diesel Power Plant (DPP). On the other hand, high capacity power plant using UCG gas may be constructed in a location close to the interconnected electricity network.

Estimated electricity peak load in the year 2018 in the province is $654 \mathrm{MW}$. With the growth of electricity demand around $7 \%$ per year, the peak load in 2027 will be around $1.169 \mathrm{MW}$ or additional 60MW power plant should be constructed every year.

Natural Gas consumers in Kalimantan region are Bontang LNG Plant, Fertilizer and Petrochemical plant, Power Plant, Industry \& Commercial, Pertamina RU V Balikpapan Oil Refinery and City Gas for Tarakan, Bontang, Samarinda, Balikpapan, and Bulungan. Despite the above demand, construction of UCG to substitute natural gas plant in Kalimantan in the short term (2018-2027) is not attractive due to natural gas production surplus in Region $\mathrm{V}$ (Kalimantan). If the plant must be constructed, the product should be supplied to other regions (region II, III or IV) that have experienced a natural gas supply deficit.

\section{CONCLUSION}

Eleven potential coal basins in Indonesia have been evaluated their coal characteristics for UCG development. Parameters used for the evaluation are coal rank, thickness, depth, and composition. Coal rank must be bituminous or lower, coal layer thickness must be more than $5 \mathrm{~m}$, coal layer depth must be more than $200 \mathrm{~m}$ and sum of coal ash plus moisture content must be below $60 \%$.

This preliminary study reveals that Indonesian has four potential coal basins to be developed by UCG, with coal resources calculated from those basins in South Sumatera basin, Barito basin, Pasir/Asemasem basins, and Kutai basins are 801 million tons (MT), $436 \mathrm{MT}, 136 \mathrm{MT}$ and 289.7 MT, respectively and have hypothetic gas resources total of 8.38 TSCF. The resources will be much bigger if the whole area of each basin is explored.

UCG Plant in the South Sumatra basin should produce synthetic natural gas since natural gas balance in this region is deficit while electricity CRE is low. On the contrary, UCG Plant in Kalimantan should produce electricity since CRE of electricity is high and natural gas balance in this region is surplus.

\section{ACKNOWLEDGEMENT}

The authors would like to thank the Head of Agency of R\&D for Energy and Mineral Resources, Head of Research and Development Center for Mineral and Coal Technology/tekMIRA, Researchers at tekMIRA, Coal and Geothermal Mineral Resources Center for providing the information to enrich this paper.

\section{REFERENCES}

Advanced Resources International (2003) 'Indonesian coalbed methane: Task 1 Resources assessment'. Virginia: Advanced Resources International, p. 187.

Badan Standardisasi Nasional (2011) SNI 50152011: Pedoman pelaporan, sumberdaya, dan cadangan batubara. Jakarta. Available at: http://www.perhapi.or.id/doc/sni5015.pdf.

van Bemmelen, R. W. (1949) The geology of Indonesia. The Hague, Martinus Nijhoff.

Bhutto, A. W., Bazmi, A. A. and Zahedi, G. (2013) 'Underground coal gasification: From fundamentals to applications', Progress in Energy and Combustion Science, 39(1), pp. 189-214.

doi: 10.1016/j.pecs.2012.09.004.

Burchart-Korol, D., Krawczyk, P., CzaplickaKolarz, K. and Smoliński, A. (2016) 'Ecoefficiency of underground coal 
gasification (UCG) for electricity production', Fuel, 173, pp. 239-246. doi: 10.1016/j.fuel.2016.01.019.

Darman, H. and Sidi, F. H. (eds) (2000) An outline of the geology of Indonesia. Jakarta: Indonesian Association of Geologists.

Dewan Energi Nasional (2017) 'Ketahanan energi nasional'. Jakarta: Dewan Energi Nasional. Available at: https://www.den.go.id/index.php/publika si/download/61.

Friedmann, S. J., Upadhye, R. and Kong, F.-M. (2009) 'Prospects for underground coal gasification in carbon-constrained world', Energy Procedia, 1(1), pp. 4551-4557. doi: 10.1016/j.egypro.2009.02.274.

Hall, R. (2009) 'Hydrocarbon basins in SE Asia: understanding why they are there', Petroleum Geoscience, 15(2), pp. 131146. doi: 10.1144/1354-079309-830.

Hattingh, L. (2008) 'Underground coal gasification'. Sasol Mining, p. 28. Available at: http://www.sacea.org.za/docs/UNDERG ROUND COAL GASIFICATION - Lian Hattingh.pdf.

Imran, M., Kumar, D., Kumar, N., Qayyum, A., Saeed, A. and Bhatti, M. S. (2014) 'Environmental concerns of underground coal gasification', Renewable and Sustainable Energy Reviews, 31, pp. 600-610. doi: 10.1016/j.rser.2013.12.024.

Khadse, A., Qayyumi, M., Mahajani, S. and Aghalayam, P. (2007) 'Underground coal gasification: A new clean coal utilization technique for India', Energy, 32(11), pp. 2061-2071. doi: 10.1016/j.energy.2007.04.012.

Kreynin, E. V. (2012) 'An analysis of new generation coal gasification projects', International Journal of Mining Science and Technology, 22(4), pp. 509-515. doi: 10.1016/j.jimst.2012.01.012.

Maev, S., Blinderman, M. S. and Gruber, G. P. (2018) 'Underground coal gasification (UCG) to products: Designs, efficiencies, and economics', in Blinderman, Michael S. and Klimenko, A. Y. (eds) Underground Coal Gasification and Combustion. Elsevier, pp. 435-468. doi: 10.1016/B978-0-08-100313-8.00013-X.
Minister of Energy and Mineral Resources (2012) Decree No. 2700K/11/MEM/2012 about master plan national gas transmission and distribution network for 2012-2025. Indonesia. Available at: https://jdih.esdm.go.id/peraturan/Kepme n-esdm-2700-2012.pdf.

Minister of Energy and Mineral Resources (2018) Decree No. 1772K/20/MEM/2018 about the amount of the basic cost of providing PT. Electric Company Negara (Persero). Indonesia.

Nakaten, N., Schlüter, R., Azzam, R. and Kempka, T. (2014) 'Development of a techno-economic model for dynamic calculation of cost of electricity, energy demand and $\mathrm{CO} 2$ emissions of an integrated UCG-CCS process', Energy, 66 , pp. $779-790$.

doi: 10.1016/j.energy.2014.01.014.

Nakaten, N., Islam, R. and Kempka, T. (2014) 'Underground coal gasification with extended CO2 utilization - An economic and carbon neutral approach to tackle energy and fertilizer supply shortages in Bangladesh', Energy Procedia, 63, pp. 8036-8043.

doi: 10.1016/j.egypro.2014.11.840.

Oliver, R. L. and Dana, G. F. (1991) 'Underground coal gasification', in Geology in coal resource utilization. Peters D.C. Techbooks, pp. 155-168.

PT PLN (2018) 'RUPTL PT PLN Persero 20182027'. Jakarta: PT PLN, p. 41. Available at:

http://www.djk.esdm.go.id/pdf/RUPTL/03 - 22 - 2018 RUPTL 2018-2027 PLN.pdf.

Pusat Sumberdaya Mineral Batubara dan Panas Bumi (2016) 'Executive summary: Pemutakhiran data dan neraca sumberdaya mineral'. Pusat Sumber Daya Mineral Batubara dan Panas Bumi, p. 14. Available at: https://www.scribd.com/document/37466 5010/Executive-Summary-NeracaMineral-Psdmbp-2016.

Santoso, B. (2015) Petrologi batubara Sumatra dan Kalimantan: jenis, peringkat, dan aplikasi. Jakarta: LIPI Press.

Sukamto, R. (1982) 'Geological map of Pangkajene and Watampone Quadrangles, scale 1:250.000'. Bandung: Indonesian Geological Research and Developmet Centre. 